\title{
Doctors accused of doing illegal stem-cell trials
}

An apparently successful stem-cell treatment for urinary incontinence is now being questioned after it has emerged that clinical trials for the therapy may have been done illegally.

Patients who received the stem-cell procedure in operations at a hospital in Innsbruck, Austria, are now taking legal action against the hospital's management, in a scandal that goes right to the heart of the country's health ministry.

Next week, a civil court will hear the case of 70-year-old Dieter Bollmann from Berlin, who paid more than $€ 11,000$ (US $\$ 17,000$ ) for the procedure in 2005 . He claims that urologists, led by Hannes Strasser, at the University Hospital Innsbruck told him that the treatment had a very high success rate, and implied that clinical trials had been completed. The consent form that Bollman signed, and which Nature has seen, does not include the word 'experimental.' The operation did not improve his symptoms.

Bollmann is suing TILAK, the administrative body that runs the university hospital, for $€ 4,000$ damages, in a suit he originally filed in 2006. Around that time, TILAK told Strasser and his team not to do any further operations outside of a formal clinical trial. A TILAK spokesman has told local newspapers that the team carried out a further 60 or so. In all, hundreds of patients have been treated outside

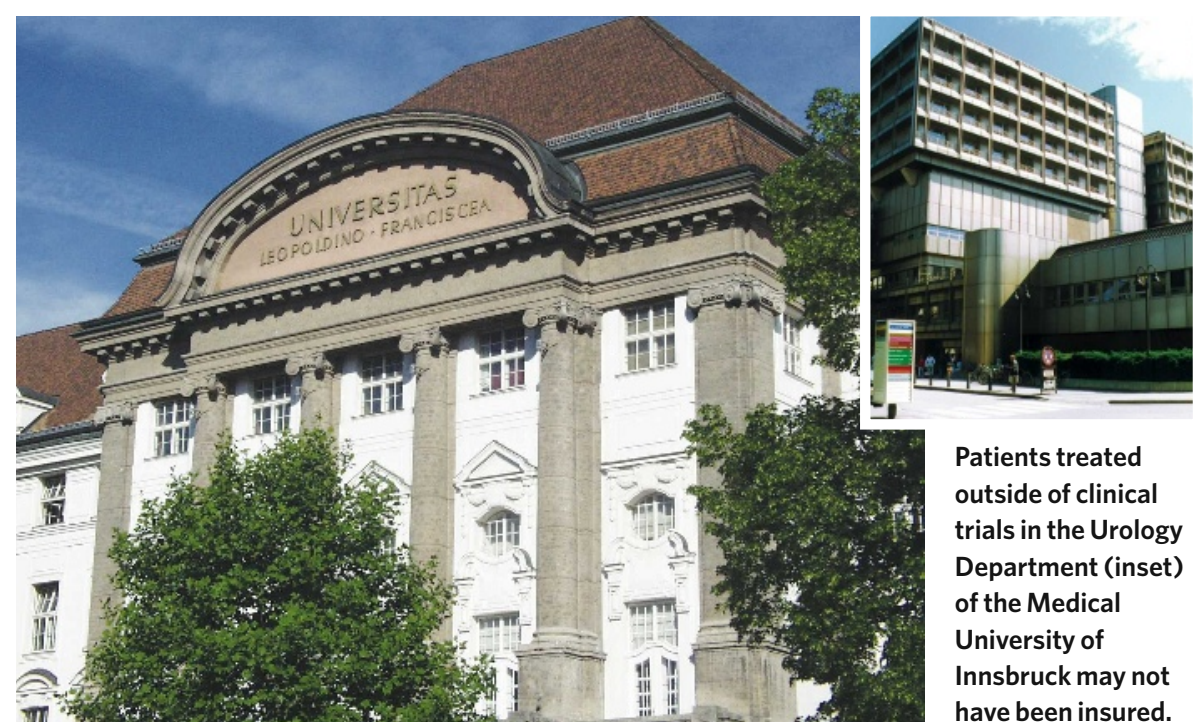

of clinical trials, it is alleged. A preliminary investigation by Austria's ministry of health has found that such patients are not insured for experimental procedures.

And the issue goes deeper. The independent ethics committee that approves and oversees clinical trials at the university and hospital is now concerned that the clinical trial of the procedure's efficacy, carried out by Strasser's team and published in The Lancet last June, may have been illegal. The Ministry of Health is now investigating claims by the ethics committee that it was never contacted, as law requires, about the trial on 63 women who were recruited between 2002 and 2004 (H. Strasser et al. Lancet 369, 2179-2186; 2007). And some members of the committee claim that documents may have been created to cover up omissions. Further probing reveals apparent irregularities that trace back to the ministry itself.

Strasser's involvement with the ethics committee began in 2001, when he applied to conduct phase I pilot studies on his technique, to establish its safety. His procedure involves culturing muscle stem cells and fibroblasts from a small sample of tissue taken from a patient's arm. The cultured cells, produced by Innovacell Biotechnology, a company co-founded and co-owned by Strasser, are then injected into the same patient's urinary sphincter, the muscle at the base of the bladder that

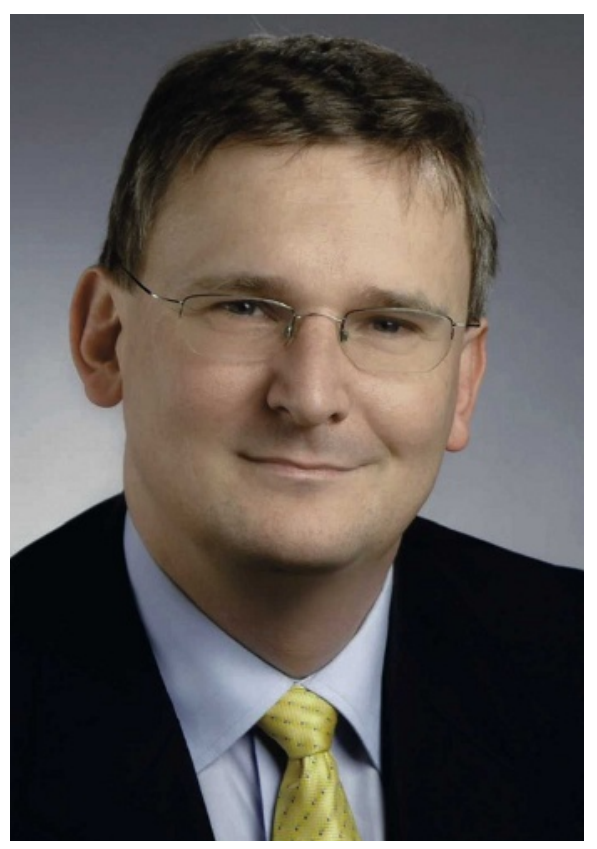

Clinical trials led by Hannes Strasser have come under scrutiny by an Austrian ethics committee.

controls urine flow, where the cells are intended to promote new muscle growth and so increase the power of the sphincter.

The committee initially denied approval because the submission lacked data on, for example, animal experiments, which are necessary before new medical interventions can be used in humans. A year later the scientists provided these data and obtained approval from the Ministry of Health's technical committee. The university ethics committee then approved two phase I studies, in 2002 and 2003, in a total of 25 patients. Eventually, just 21 were recruited.

It was not until March 2007 that the urologists applied formally to undertake a phase II clinical trial - to assess the efficacy of their technique - on 100 patients. They included the draft of their Lancet paper in the supporting data they provided to the ethics committee. This was how the committee learnt that a randomized, controlled trial of 63 women had already been conducted without its approval.

The trial published in The Lancet states that it is registered on controlled-trials.com, however the reference number provided leads not to a national trial database but to an approval for the production of therapeutic cells by Innovacell.

The authors of the Lancet paper say that their trial was approved by the Ministry of Health on 27 August 2002. It is illegal under European (and Austrian) law for a trial to get the go-ahead without independent ethics approval. "The last time that the government gave approval for experiments on humans 
without the input of an independent ethics committee was during the Third Reich," says Andreas Scheil, a professor of law at the University of Innsbruck and a member of the ethics committee.

Last October, in response to the committee's inquiries, Hubert Hrabcik, the director of the Ministry of Health's office for public health, wrote a letter to the committee saying that the legal situation was ambiguous but there seemed to be no obligation to approach an independent ethics committee.

But shortly after Hrabcik sent his letter, the urologists surprised the committee by suddenly producing the first page of an application to the health ministry for a phase III study of $90-100$ patients, with the same registration number as the 2001 application - and dated to the same month - as the phase I study that had been denied. The committee says that it never saw this document, and some members have questioned its authenticity.

Strasser and his department head Georg Bartsch, who is also a witness in the Bollmann case, are currently under a gagging order. But their lawyer Dietmar Czernick told Nature that they did not require ethics approval for operations done outside of clinical trials. These treatments began after the clinical trial had been completed, although not yet published, Czernick claims, and at that point they considered the procedure to be "well-established therapy".

Czernick claims that Strasser and Bartsch believed they didn't need ethics approval for the trial itself because the law was "complicated and unclear" on the point. "They had the approval of the federal Ministry of Health which did the job of an ethics committee", Czernick says.

Financial issues are muddying the situation. TILAK paid an estimated $€ 1.2$ million for Innovacell materials for 200 patients, for trials it now thinks may have been uninsured and unapproved. Normally the sponsor of a trial - in this case Innovacell - pays such costs itself.

No one is suggesting that the procedure is harmful to patients. But researchers carrying out the treatment at sites outside Austria have not had the high success rate reported by the Innsbruck team. "It looks tremendously good, but as always it is important to repeat the good results in independent sites," says Giacomo Novara, a urologist at the University of Padua, Italy.

The Lancet is publishing an 'expression of concern' in its 3 May issue about the confusing reference number in the registration document in the trial they published. "We will wait for the outcome of the investigations before deciding about further actions," says the journal's senior executive editor Sabine Kleinert.

Alison Abbott

nWh marnarasums

Vote on which story you would like us to cover in more depth.

www.nature.com/news

\section{US ocean-research projects in dire economic straits}

America's fleet of research ships is struggling in financial doldrums threatening marine projects around the globe. The number of vessels is shrinking, funding for new vessels is being sidetracked and the forecast is for even fewer ships and higher costs. Already, the annual number of research days at sea has been cut by $20 \%$.

"When the cost of equipment is driving the agenda, that is a death knell for a field," says geophysicist Marcia McNutt of the Monterey Bay Aquarium Research Institute in Moss Landing, California, who chairs the US research fleet's governing council. "You end up doing what research you can do, instead of what research you should do."

The fleet is overseen by the UniversityNational Oceanographic Laboratory System (UNOLS), a consortium of 61 research institutes. The ships are affiliated to various institutions and provide vital platforms for scientists investigating topics from ocean chemistry and circulation to sea-floor core extractions. Annually, the fleet now provides about 4,000 research days at sea, down from about 5,000 before 2000, UNOLS officials say.

The UNOLS receives US $\$ 80$ million a year for fleet operation directly from the federal budget. This year, the funds have been supplemented by money from a private foundation and a Saudi university. Research teams apply to funding agencies, such as the US National Science Foundation (NSF), for individual scientific cruises - ship time for a deepsea cruise runs at about $\$ 50,000$ per day.

There are 23 ships currently in service, varying from regional vessels for nearcoast studies to oceanic cruisers. In 2002, there were 27 ships. By 2017, 15 ships are

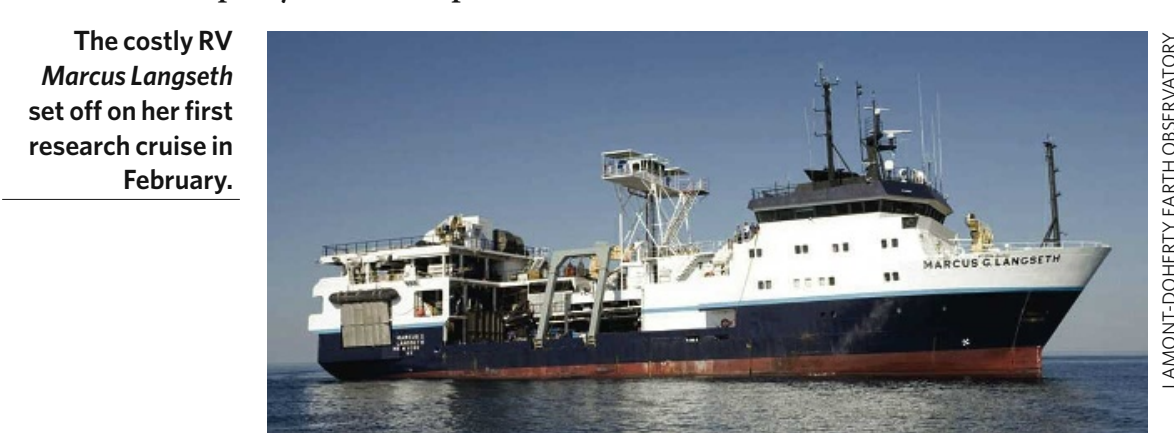

projected, with only 11 by 2025 - at which time the global vessels would be down to three from today's six.

It takes years to design and refit or build a ship. For more than four years, the NSF, which funds most ship projects, has been planning to build a $\$ 123$ million Alaska-region research ship to replace a decommissioned vessel. But there is no ship funding in the NSF budget that is now before Congress - and long-term funding is unknown.

The ship RV Marcus Langseth, which will be the first ship to carry out threedimensional models of the undersea crust, offers an example of the challenges faced. The newly rebuilt Langseth undertook her first research cruise in February after long delays and vast cost-overruns, involving difficulties securing high-tech crew members who are also sought by oil and gas companies, and costly problems operating its seismic system for visualizing seafloor formations. NSF officials say an audit is underway on the Langseth project, where costs at a Nova Scotia shipyard were $\$ 600,000$ above the bid of $\$ 4.4$ million for refitting. A worldwide lack of available shipyard space means that costly delays are systemic in the shipbuilding industry.

The JOIDES Resolution, a core-drilling vessel, is another delayed ship. It was to have been rebuilt by the end of 2007, but now isn't expected to be ready until at least August. The Integrated Ocean Drilling Program, an international partnership of scientists and research institutions that operates the ship, says the Singapore shipyard doing the refit will consume all contingency funds in the $\$ 32$ million retrofit budget, funded by the NSF. Rex Dalton 